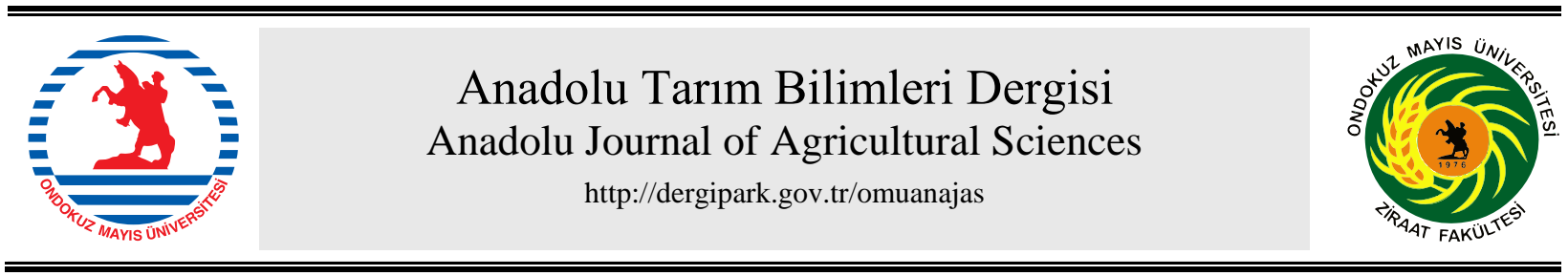

Araştırma/Research

Anadolu Tarım Bilim. Derg./Anadolu J Agr Sci, 36 (2021) ISSN: 1308-8750 (Print) 1308-8769 (Online) doi: 10.7161/omuanajas.827263

\title{
Pırasa ve yer fistı̆̆ 1 yetiştirilen toprakların verimlilik durumları ile ağır metal içerikleri: İzmir-Torbalı ve Çanakkale-Bayramiç ilçeleri örnek çalışmaları
}

\author{
๑DMehmet Parlak ${ }^{\mathrm{a}^{*}}$, (T) Timuçin Everest ${ }^{\mathrm{a}}$, (1)Tülay Tunçay ${ }^{\mathrm{b}}$ \\ ${ }^{\mathrm{a} C ̧ a n a k k a l e ~ O n s e k i z ~ M a r t ~ U ̈ n i v e r s i t e s i, ~ L a p s e k i ~ M e s l e k ~ Y u ̈ k s e k o k u l u, ~ L a p s e k i, ~ C ̧ a n a k k a l e, ~ T u ̈ r k i y e ~}$ \\ b T.C. Tarım ve Orman Bakanlığı, Toprak, Gübre ve Su Kaynakları Merkez Araştırma Enstitüsü, Ankara, Türkiye \\ *Sorumlu yazar/corresponding author: mehmetparlak06@hotmail.com
}

Geliş/Received 17/11/2020～Kabul/Accepted 24/05/2021

\begin{abstract}
ÖZET
Pırasa ile yer fistığı İzmir'in Torbalı ve Çanakkale'nin Bayramiç İlçesi’nde ekonomik getirisi yüksek olan bitkilerdendir. Pırasa ve yer fıstığından optimum verim alabilmek için toprak özelliklerinin bilinmesi gereklidir. $\mathrm{Bu}$ araştırmanın amacı pırasa ve yer fistığı tarımı yapılan toprakların fizikokimyasal özelliklerini, besin elementleri içeriklerini, ağır metallerin zenginleşme faktörlerini ve kirlilik faktörlerini saptamaktır. Pırasa yetiştirilen toprakların tın, kumlu kil tın, killi tın bünyede; yer fıstığı yetiştirilen toprakların ise kumlu tın, tınlı kum ve kil bünyeli oldukları belirlenmiştir. Pırasa ve yer fistığ 1 yetiştirilen alanların genellikle nötr ve hafif alkali reaksiyonlu, tuzsuz ve kireçli topraklar oldukları saptanmıştır. Organik madde kapsamı bakımından pırasa yetiştirilen toprakların \% 92.59'unun az, \% 7.41'inin orta; yer fistığı yetiştirilen toprakların ise \% 55.56'sının çok az, \% 44.44'ünün az oldukları belirlenmiştir. Pırasa ve yer fistığı tarımı yapılan toprakları tamamının toplam $\mathrm{N}$ bakımından az, alınabilir $\mathrm{P}, \mathrm{Ca}, \mathrm{Mg}, \mathrm{Fe}, \mathrm{Cu}$ ve $\mathrm{Mn}$ bakımından sorun içermedikleri saptanmıştır. Alınabilir $\mathrm{Zn}$ bakımından pırasa yetiştirilen toprakların \%7.41'inin, yer fistığı yetiştirilen toprakların ise \% 83.33'ünün sorunlu olduğu belirlenmiştir. Ağır metallerin zenginleşme faktörü pırasa yetiştirilen topraklarda $\mathrm{EF}_{\mathrm{Cu}}>\mathrm{EF}_{\mathrm{Zn}}>\mathrm{EFNi}>\mathrm{EF}_{\mathrm{Mn}}>\mathrm{EF}_{\mathrm{Pb}}>\mathrm{EF}_{\mathrm{Cr}}$ iken yer fistığ $\mathrm{EF}_{\mathrm{Cu}}>\mathrm{EF}_{\mathrm{Ni}}>\mathrm{EF}_{\mathrm{Pb}}>\mathrm{EF}_{\mathrm{Mn}}>\mathrm{EF}_{\mathrm{Cr}}>\mathrm{EF}_{\mathrm{Zn}}$ sıralamasında saptanmıştır. Hem pırasa hem de yer fistığ 1 yetiştirilen topraklarda Cu'nun kirlilik faktör sınıfı orta kirlilikte iken diğer ağır metaller ise (Mn, Zn, $\mathrm{Cr}$, Ni ve $\mathrm{Pb}$ ) düşük kirlilik sınıfında belirlenmiştir.
\end{abstract}

Fertility and Heavy Metal Contents of Leek and Peanut-Grown Soils: The Sample Case of İzmir-Torbalı and Çanakkale-Bayramiç Towns

\section{ABSTRACT}

Leek and peanut are the major crops with high economic returns in Torbalı town of Izmir and Bayramiç town of Çanakkale. Soil characteristics should be well-known to get optimum yields from leek and peanut. This study was conducted to investigate the physico-chemical characteristics, nutrient contents, heavy metal enrichment factors and pollution factors of leak and peanut-grown soils. Leek-grown soils were loamy, sandy-clay-loam and clayey-loam in texture and peanut-grown soils were sandy-loam, loamy sand and clay in texture. Leek and peanut-grown soils generally had neutral and slightly alkaline reaction, were unsaline and rich in lime. Of leek-grown soils, $92.59 \%$ had low and $7.41 \%$ had moderate organic matter contents. Of peanut-grown soils, $55.56 \%$ had quite low and $44.44 \%$ had low organic matter contents. Leak and peanut-grown soils were insufficient in $\mathrm{N}$ and sufficient in available $\mathrm{P}, \mathrm{Ca}$, $\mathrm{Mg}, \mathrm{Fe}, \mathrm{Cu}$ and $\mathrm{Mn}$. In terms of available Zn content, 7.41\% of leek-grown soils and 83.33\% of peanutgrown soils had problems. Heavy metal enrichment factors were ordered as $\mathrm{EF}_{\mathrm{Cu}}>\mathrm{EF}_{\mathrm{Zn}}>\mathrm{EF}_{\mathrm{Ni}}>\mathrm{EF}_{\mathrm{Mn}}>\mathrm{EF}_{\mathrm{Pb}}>\mathrm{EF}_{\mathrm{Cr}}$ for leek-grown soils and as $\mathrm{EF}_{\mathrm{Cu}}>\mathrm{EFNi}>\mathrm{EF}_{\mathrm{Pb}}>\mathrm{EF}_{\mathrm{Mn}}>\mathrm{EF}_{\mathrm{Cr}}>\mathrm{EF}_{\mathrm{Zn}}$ for peanut-grown soils. In both leek and peanut-grown soils, $\mathrm{Cu}$ pollution factor was classified as moderate and the pollution factor for the other heavy metals ( $\mathrm{Mn}, \mathrm{Zn}, \mathrm{Cr}, \mathrm{Ni}$ and $\mathrm{Pb}$ ) were classified as low.
Anahtar Sözcükler:

Ağır metaller

Kirlilik faktörü

Pirasa

Yer fistığ1

Toprak özellikleri

Zenginleşme faktörü
Keywords:

Heavy metals

Pollution factor

Leek

Peanut

Soil properties

Enrichment factor

(c) OMU ANAJAS 2021 


\section{Giriş}

İnsanların yaşamlarında önemli bir role sahip olan toprak canlıların gıda, temiz hava ve su gibi mutlak ihtiyaç duyduğu gereksinimleri karşılamakla birlikte biyoçeşitlilik havuzu olarak işlev görmekte ve atmosferdeki karbonun tutulmasında etkili olmaktadırlar (Keesstra ve ark., 2016). Toprakların sürdürülebilirliğini olumsuz yönde etkileyen faktörlerden birisi çeşitli kaynaklar aracılığıyla topraklara ilave olan kirleticilerdir. En önemli kirleticilerden birisi olan ağır metaller; tarım topraklarında daha az çözünebilir formlarda biriktikleri, toprak çözeltisine taşınabildikleri, yeraltı suyu ve bitki kalitesini bozabildikleri için daha çok dikkat çekmektedirler. Bitkiler insanların oral yolla beslenmesinde önemli bir kaynaktır. Tarım topraklarında ağır metallerin dikkatli bir şekilde izlenmesi, sürdürülebilir geleceği sağlamak ve korumak için önemlidir. Tarım topraklarındaki ağır metallerin konsantrasyonları ana materyalin bileşimine göre düşük olabilir. Diğer taraftan tarım topraklarındaki ağır metallerin antropojenik girdilerinin nedenleri; atık sularla sulama, tarımsal kirleticiler, ahır gübresi kullanımı ve petrokimyasal aktivitelerdir. Gübreler topraktaki besin maddelerinin sağlanmasında ve hasat için zorunlu olmasına rağmen, gübreler ile metal içeren pestisit ve fungusitlerin uzun dönem uygulanması topraklarda toksik elementlerin birikmesine neden olabilir. Gübreler; uygulama düzeyleri ve hammadde kaynağına göre ağır metalleri toprağa ilave ederler. Yoğun tarımsal kimyasalların uygulanması sonucunda topraklar $\mathrm{Cu}, \mathrm{Zn}, \mathrm{Cd}$ gibi ağır metallerce zenginleşir (Kelepertzis, 2014).

Pırasa ülkemizde kışlık sebze olarak kullanılan ve bütün bölgelerimizde üretilip tüketilen bir sebzedir. Pırasa ülkemizde kışlık sebze tüketiminin çok önemli bir bölümünü oluşturur ve beslenmede önemli bir yeri vardır (Vural ve ark., 2000). Pırasanın dünya ve Türkiye ekonomisindeki yeri nedeniyle pırasayla ilgili araştırılmaların sürdürülmesi gerekmektedir. Dünyada 2017 yılında 142509 ha alanda 1499769 ton pırasa ve diğer soğansı sebze üretimi gerçekleştirilmiştir. 2017 yılında dünyada pırasa ve diğer soğansı sebzelerin en fazla ekildiği ülkeler Endonezya (60 953 ha), Ruanda (15 229 ha), Türkiye (7 312 ha), Polonya (6 475 ha), Çin (5 661 ha), Belçika (4 723 ha) ve Fransa'dır (4 677 ha) (Anonim, 2019a). Türkiye' de 2018 yılında 252958 ton pırasa üretimi gerçekleşmiştir. İzmir'in Torbalı ilçesindeki pırasa üretimi Türkiye' deki üretimin yaklaşık \%16' sını (39 760 ton) karşılamaktadır (Anonim, 2019b).

Yer fistığı bir yağ bitkisi olmakla beraber pek çok kullanma yeri ve yan ürünü vardır. Bu nedenle sanayinin önemli hammaddesini oluşturur. Baklagil ve çapa bitkisi olması nedeniyle tarla tarımında, toprağı biyolojik ve fiziki bakımdan 1slah edici olarak önemi yüksektir. Ekonomik olarak dünya bitkisel yağ üretiminin \% 90'ını 13 çeşit yağ bitkisinin karşıladığı bir ortamda, yer fistığı soya ve kolzadan sonra önem sırasına göre 3. sırayı almaktadır. Yer fistığı tohumlarında \% 47-55 oranında yağ vardır. Bu yağ yemeklik olarak katı ve sıvı halde kullanılır. Yağı alındıktan sonra geriye kalan küspesi iyi bir hayvan yemidir. Yer fistığı kabuklarından suni tahtalar yapıldığ gibi kabuğu kuru ot yerine kaba yem olarak da kullanılır. Yer fistığı tohumları ribolavin, thiamin, niacin ve E vitaminlerini içerir. Tohumlarından elde edilen yağı; yemeklik olarak katı ve sıvı halde, balık konserveciliğinde, bisküvi, pasta, şekerleme üretiminde kullanılır. ABD'de yer fistığı ezmesi peanut butter ismiyle kahvaltılarda ekmeklerin üzerine sürülerek gida olarak tüketilmektedir. Yer fistığı azot bakterileri aracıllğıyla diğer baklagiller gibi toprakta azot biriktirir. Tohumları kavrularak çerez olarak da tüketilmektedir. Kabuksuz tanesindeki biyolojik değeri yüksek protein miktarı \% 25 civarındadır. Bu bakımdan gelişmiş ve gelişmekte olan birçok ülkede hayvansal protein açığını kapatmak amacıyla iç tüketimde değerlendirilmektedir (Geçit ve ark., 2011). 2013 yılında dünyada 45.7 milyon ton yer fistığı üretilmiştir. Dünyada Çin 16.97 milyon ton ile birinci sırada (\%37) yer almaktadır. Hindistan 9.47 milyon ton (\% 20), Nijerya 3 milyon ton (\% 6.5), ABD 1.89 milyon ton (\% 4.1) ve Sudan 1.76 milyon ton (\% 3.8) yer fistığ üretmiştir. 2013 yılı verilerine göre Türkiye' de 1.41 milyon ton üretim yapılmıştır (DOĞAKA, 2015). Türkiye' de 2018 yılında 173835 ton kabuklu yer fistığı üretimi yapılmıştır. 2018 yılında ise Türkiye' de yer fistığı tarımının en fazla yapıldığı iller Adana (239 584 da), Osmaniye (130 275 da), Aydın (10 965 da), Mersin ( 9824 da) ve Kahramanmaraş’tır (8 425 da). Çanakkale’nin Bayramiç ilçesindeki kabuklu yer fistığı üretimi 59 tondur (Anonim, 2019b).

Bu araştırmanın amacı İzmir' in Torbalı ve Çanakkale' nin Bayramiç ilçesinde pırasa ve yer fıstığı tarımı yapılan toprakların verimlilik durumları ile alınabilir ve toplam ağır metal içerikleriyle beraber zenginleşme faktörü ve kirlilik faktörü gibi kirlenme indislerini belirlemektir.

\section{Materyal ve Yöntem}

\section{1 Çalı̧̧ma alanları}

Torbalı İlçesi İzmir kent merkezine $46 \mathrm{~km}$ uzaklıkta olan, $38^{\circ} 09^{\prime}$ kuzey paralelleri ile $27^{\circ} 23^{\prime}$ doğu meridyenleri arasında kalmaktadır (Şekil 1). Torbalı'nın doğusunda Bayındır ve Tire, batısında Menderes, kuzeyinde Buca ve Kemalpaşa ve güneyinde Selçuk ilçeleri vardır. 


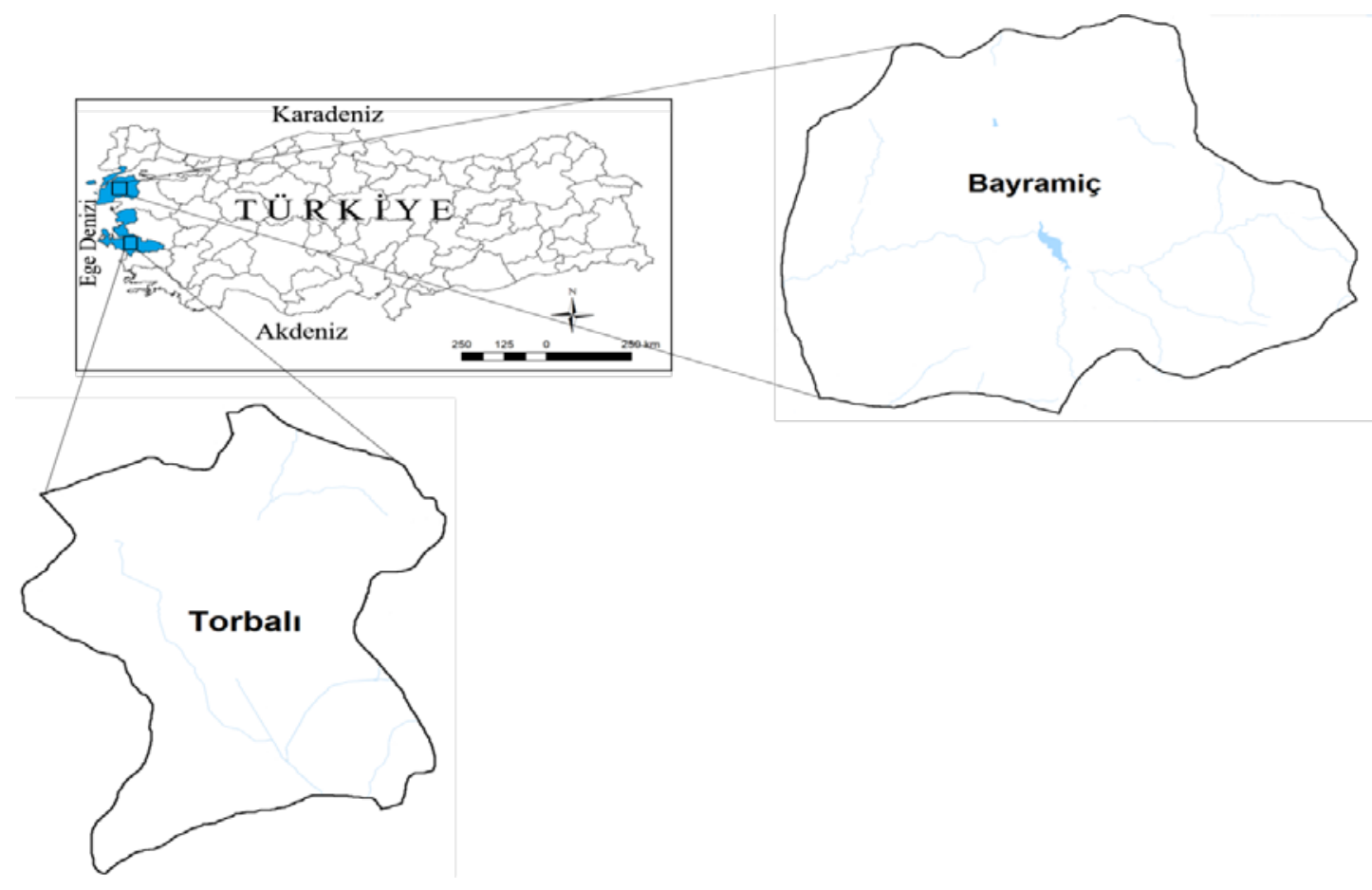

Şekil 1. Çalışma alanlarının konumları

Figure 1. Location of study areas

Tektonik faaliyet sonucu oluşan graben konumundaki Torbalı ilçesi, Fetrek Çayı'nın alüvyon düz arazisi üzerinde yer alır ve düz bir ova görünümündedir. İlçenin çevresinde yüksek araziler (horst) vardır. Torbalı ovası bölgenin en genç arazi formunu oluşturur. İlçedeki arazi şekilleri, 3. jeolojik dönemden sonra bugünkü şekline kavuşmuştur. Torbalı ilçesi, yazları sıcak ve kurak, kışları ise 1lık ve yağışlı bir özelliğe sahip Akdeniz iklimi etkisi altındadır (Kurucu ve Küçükyılmaz Christine, 2008).Torbalı ilçesindeki topraklar Toprak Taksonomisine göre Typic Xerofluvents ve Typic Haploxererts olarak sınıflandırılmıştır (Soil Survey Staff, 2014). Torbalı İlçesi verimli tarım alanları, iklimi, jeopolitik konumu, sanayileşme gibi çeşitli nedenlerle tarımsal üretim ve hayvansal üretim potansiyeli oldukça yüksektir. Ancak sanayinin gelişmesiyle tarım arazileri daralmaya başlamış ve geleneksel tarım ürünleri yetiştiriciliği ile bu ürünlerin sanayisinde artış yaşanmıştır. İlçede domates, pırasa, karnabahar, zeytin, üzüm, incir, şeftali ve mısır başlıca yetiştirilen ürünlerdir (Anonim, 2020a).

Çanakkale'nin Bayramiç İlçesi Biga yarımadasının orta bölümünü oluşturan, 38-40 kuzey enlemleri ile 26-28 doğu boylamları arasında yer alan bir ilçe olup yarı dağlık bir alan üzerine kuruludur (Şekil 1). Bayramiç'in doğusunda Çan ve Yenice, batısında Ezine, güneyinde Ayvacık ilçesi ve Balıkesir ili, kuzeyinde Çanakkale merkez ilçesi vardır. Bayramiç'i güney, doğu ve kuzeyde bir yay biçiminde kuşatan dağlık alanın ortasında eski Menderes Çayı ve vadisi yer alır (Anonim, 2020b). Kazdağı'ndan çıkan akarsuların beslediği Menderes Çayı'nın geniş taban vadisi içinde oluşturduğu Bayramiç-Ezine ovası geniş ve kalın birikinti tabakası (alüvyon) ile örtülü olup, her türlü tarıma elverişlidir. Elma, zeytin, armut, badem ve şeftali yetiştirilen başlıca bitkilerdir. İklim coğrafi bakımdan Marmara İklim bölgesine girer. Yazları sıcak ve kurak, kışları yağışlı ve Akdeniz İklimine göre soğuk geçer (Anonim, 2020c). Bayramiç ilçesindeki topraklar Toprak Taksonomisine göre Typic Ustifluvents olarak sinıflandırılmıştır (Soil Survey Staff, 2014).

\subsection{Toprak örneklerinin alınması}

Pırasa ve yer fistı̆̆ yetiştirilen tarlalardan toprak örneklerini almak için Kasım 2019'da İzmir' in Torbalı ilçesine, Eylül 2019'da Çanakkale'nin Bayramiç ilçesine gidilmiştir. Torbalı'da en çok pırasa üretimi yapılan 3 köy (Merkez, Özbey, Çapak) seçilmiştir. Pırasa üretimi yapılan tarlaların büyüklügü 5 da ile 30 da arasında değişmektedir. Pırasa tarlasının 3 farklı yerinden alınan toprak örnekleri birleştirilerek tek örnek haline getirilmiştir. Pırasa tarlalarının her birisinden rastgele örnekleme yöntemine göre 3 örnek alınmıştır. Her bir köyde 3 pırasa tarlası, her tarlada 3 tekerrür olmak üzere toplamda 27 örnekleme (3 köy x 3 tarla x 3 tekerrür=27) yapılmıştır (Şekil 2). Bayramiç İlçesi'nde de en çok yer fıstığı üretimi yapılan 2 köy (Pıtıreli, Çavuşköy) belirlenmiştir. Yer fistığı 
üretimi yapılan tarlaların büyüklüğü ise 3 da ile 10 da arasında değişmektedir. Yer fistığı tarlasının 3 farklı yerinde alınan toprak örnekleri karıştırılarak tek örnek yapılmışıtır. Yer fistığı yetiştirilen tarlaların her birinden ise rastgele örnekleme yöntemine göre 3 örnek alınmıştır. Her bir köyde 3 yer fistığı tarlası, her tarlada 3 tekerrür olmak üzere toplamda 18 örnekleme (2 köy x 3 tarla x 3 tekerrür=18) yapılmıştır (Şekil 2).

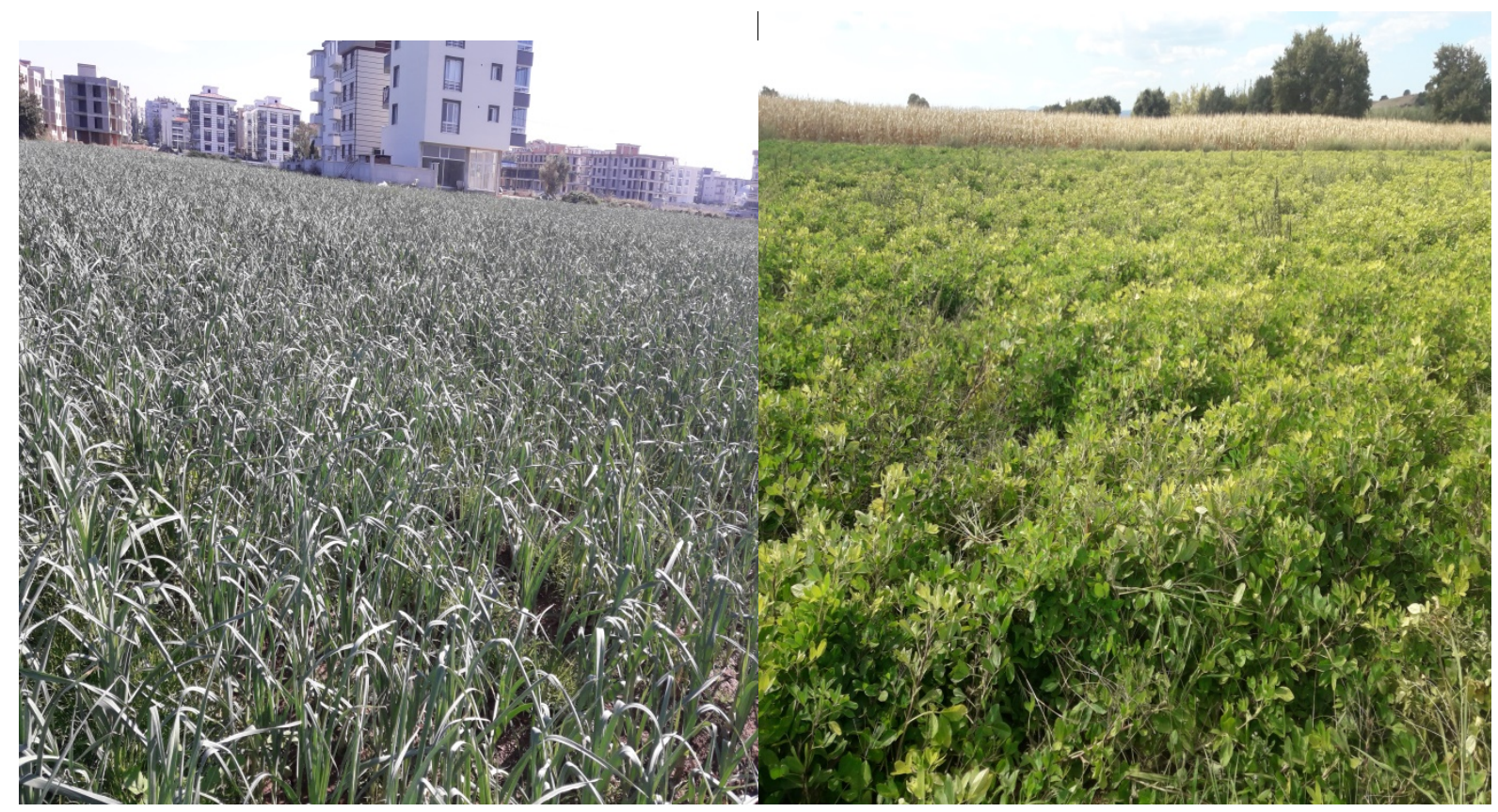

Şekil 2. Toprak örnekleri alınan pırasa ve yer fistığ tarlaları

Figure 2. Leek and peanut fields that soil samples collected

Toprakların bazı fiziksel ve kimyasal özelliklerini saptamak için toprak örnekleri 0-20 cm derinlikten Petersen ve Calvin (1996)' in belirlediği esaslara göre plastik kürekle alınmıştır. Araziden alınmış toprak örnekleri laboratuvara getirilip kurutulmuş ve tahta tokmakla dövülüp $2 \mathrm{~mm}$ ' lik elekten elenerek analizlere hazır hale getirilmiştir.

\subsection{Toprak analizleri}

Tane büyüklüğü dağılımı (bünye) için toprak örnekleri sodyum hekza metafosfat çözeltisiyle kimyasal dispersiyona ve toprak mikseri ile 6-10 dakika karıştırıldıktan sonra(fiziksel dispersiyon) 1130 ml'lik silindirlere aktarılmış ve hidrometre yardımıyla tane büyüklüğü dağılımı (bünye) belirlenmiştir (Gee ve Or, 2002). Toprak örneklerinde $\mathrm{pH}$ ve EC (elektriksel iletkenlik) ölçümleri saturasyon çamurunda yapılmıştır (Thomas, 1996; Rhoades, 1996). Organik madde modifiye edilmiş Walkley Black yönteminde belirtildiği gibi toprak örneklerinin $\mathrm{K}_{2} \mathrm{Cr}_{2} \mathrm{O}_{7}$ ile oksidasyonu ve $\mathrm{FeSO}_{4}$ çözeltisiyle titrasyonu sonucunda belirlenmiştir (Nelson and Sommers,1996). Toprak örneklerinde kireç Scheibler kalsimetresinde açığa çıkan $\mathrm{CO}_{2}$ miktarına göre belirlenmiştir (Loeppert ve Suarez, 1996). Toplam azot (N) Kjeldahl yöntemiyle (Bremner, 1996), alınabilir P Olsen metoduna göre (Kuo, 1996), alınabilir potasyum $(\mathrm{K})$ ise $1 \mathrm{~N}$ nötr $(\mathrm{pH}=7.0)$ amonyum asetat $\left(\mathrm{CH}_{3} \mathrm{COONH}_{4}\right)$ ekstraksiyonunun alev fotometresinde okunmasıyla saptanmıştır (Helmke ve Sparks, 1996). Alınabilir Ca ve Mg toprak örneklerinin $1.0 \mathrm{~N}$ nötr (pH: 7.0) amonyum asetat $\left(\mathrm{CH}_{3} \mathrm{COONH}_{4}\right)$ ile ekstrakte edilerek süzükteki Ca ve Mg'un ICP-OES cihazında okunmasıyla belirlenmiştir (Suarez, 1996). Toprak örneklerinin alınabilir ağır metal ( $\mathrm{Fe}, \mathrm{Cu}, \mathrm{Mn}, \mathrm{Zn}, \mathrm{Cr}, \mathrm{Ni}$ ve $\mathrm{Pb}$ ) kapsamları $0.005 \mathrm{M}$ dietilen triamin penta asetik asit (DTPA) $+0.01 \mathrm{M}$ kalsiyum klorür $\left(\mathrm{CaCl}_{2}\right)+0.1 \mathrm{M}$ trietanolamin (TEA) ( $\mathrm{pH}=7.3$ ) çözelti karışımı ile ekstrakte edilerek (Lindsay ve Norwell, 1978) ICP-OES cihazında belirlenmiştir. Toplam ağır metal $(\mathrm{Fe}, \mathrm{Cu}, \mathrm{Mn}, \mathrm{Zn}, \mathrm{Cr}$, $\mathrm{Ni}$ ve $\mathrm{Pb}$ ) içerikleri ise nitrik asit ve perklorik asit karışımıyla 3/1 oranında yaş yakıldıktan sonra (USEPA, 1996) ICP-OES cihazında okuma yapılarak saptanmıştır.

\subsection{Toprak kirliliği indisleri}


Zenginleşme faktörü (EF): Zenginleşme faktörü insan aktivitelerinin topraktaki ağır metal konsantrasyonuna olası etkilerini belirlemek için kullanılmaktadır (Wu ve ark., 2018). Zenginleşme faktörü (EF) aşağıdaki kullanarak belirlenmiştir.

\section{$\mathrm{EF}=\left(\mathrm{C}_{\mathrm{i}} / \mathrm{C}_{\mathrm{ref}}\right)$ örnek $/\left(\mathrm{C}_{\mathrm{i}} / \mathrm{C}_{\mathrm{ref}}\right)$ yerkabuğu $\quad$ Eşitlik (1)}

Eşitlikte $\mathrm{C}_{\mathrm{i}}=$ Toprak örneklerindeki elementin konsantrasyonu, $\mathrm{C}_{\text {ref }}=$ Referans elementin konsantrasyonunu göstermektedir. Al toprakta stabil ve bol miktarda olduğu için referans element olarak seçilmiştir. Zenginleşme faktörü (EF) sınıfları Çizelge 1' de verilmiştir. Yer kabuğunda elementlerin ortalama değerleri $\mathrm{Fe}, \mathrm{Cu}, \mathrm{Mn}, \mathrm{Zn}, \mathrm{Cr}$, Ni ve Pb sirasiyla $43200 \mathrm{mg} \mathrm{kg}^{-1}, 25 \mathrm{mg} \mathrm{kg}^{-1}, 716 \mathrm{mg} \mathrm{kg}^{-1}, 65 \mathrm{mg} \mathrm{kg}^{-1}, 126 \mathrm{mg} \mathrm{kg}^{-1}, 56 \mathrm{mg} \mathrm{kg}^{-1}$ ve $14.8 \mathrm{mg} \mathrm{kg}^{-1}$ ' $\mathrm{dır}^{\circ}$ (Wedepohl, 1995).

Kirlenme faktörü (CF): Kirlenme faktörü topraklarda elementlerin kirlenme derecesini belirlemek için kullanılmaktadır. CF aşağıdaki verilen eşitlik yardımıyla hesaplanmıştır (Hakanson, 1980).

$$
\mathrm{CF}=\left(\mathrm{C}_{\mathrm{i}} / \mathrm{C}_{\mathrm{o}}\right) \quad \text { Eşitlik (2) }
$$

Eşitlikte $\mathrm{C}_{0}$ metalin yerkabuğundaki ortalama konsantrasyonunu göstermektedir. Kirlilik faktörü (CF) sınıfları Çizelge 1' de verilmiştir.

Çizelge 1. Kirlenme indisleri ve kirlilik düzeyleri

Table 1. Pollution indexes and pollution levels

\begin{tabular}{ccc}
\hline & Değer & Toprak kalitesi \\
\hline Zenginleşme faktörü & $\mathrm{E}_{\mathrm{F}}<2$ & Minimum zenginlikten düşük \\
& $2 \leq \mathrm{E}_{\mathrm{F}}<5$ & Orta zenginlikte \\
$5 \leq \mathrm{E}_{\mathrm{F}}<20$ & Yeterli oranda zenginlikte \\
$20 \leq \mathrm{E}_{\mathrm{F}}<40$ & Yüksek oranda zenginlikte \\
& $\mathrm{E}_{\mathrm{F}} \geq 40$ & Aşırı derecede yüksek zenginlikte \\
\hline Kirlenme faktörü & $\mathrm{CF}<1$ & Düşük kirlilik \\
& $1 \leq \mathrm{C}_{\mathrm{F}}<3$ & Orta kirlilik \\
& $3 \leq \mathrm{C}_{\mathrm{F}}<6$ & Önemli kirlilik \\
& $\mathrm{C}_{\mathrm{F}} \geq 6$ & Çok yüksek kirlilik \\
\hline
\end{tabular}

\section{Bulgular ve Tartışma}

Pırasa ve yer fistığ yetiştirilen toprakların bazı fiziksel ve kimyasal özellikleri Çizelge 2' de verilmiştir. Pırasa tarımı yapılan alandaki toprakların tekstür sınıfları tınlı (\% 55.55), kumlu killi tın (\% 22.22) ve killi tın (\% 22.22) iken yer fistığı tarımı yapılan alanlardaki toprakların tekstür sınıfları kumlu tın (\% 50.00), tınlı kum (\% 33.33) ve kil (\% 16.67) olarak saptanmıştır. Toprak istekleri bakımından seçici davranmayan bitki olan pırasa, tınlı ve killi topraklarda daha iyi gelişir. Organik maddece zengin topraklardan hoşlanır. En uygun toprak pH'sı 6-6.5 arasındadır (Zengin ve Özbahçe, 2011). Pırasa yetiştirilen topraklarda pH 7.52, EC $1.21 \mathrm{dS} \mathrm{m}^{-1}$ iken yer fistı̆̆ 1 yetiştirilen topraklarda pH 7.21, EC 0.65 dS m ${ }^{-1}$ olarak saptanmıştır. Aka Sağlıker ve Elmasoğlu (2020) Osmaniye'de yer fistığı yetiştirilen toprakların killi tın bünyeli, hafif alkalin reaksiyonlu ve tuzsuz olduğunu belirtmişlerdir. Pırasa yetiştirilen toprakların \% 66.67'si kireçli, \% 33.33'ü orta iken, yer fistığı yetiştirilen toprakların \% 33.33'ü az kireçli, \% 66.67'si kireçli olarak belirlenmiştir (Çizelge 3). Pırasa yetiştirilen toprakların organik madde kapsamları $\%$ 92.59'unda az, \% 7,41'inde orta düzeyde iken yer fistığı topraklarının organik madde kapsamının \% 55.56'sının çok az ve \% 44.44'ünün az olduğu saptanmıştır. Topraklarda organik madde miktarını artırmak için pırasa ve yer fistığı yetiştirilen alanlara yanmış ahır gübresi, kompost vb. verilmeli, hasat artıkları toprak yüzeyinde bırakılmalıdır. Hem pırasa hem de yer fistığı yetiştirilen toprakların tamamının toplam $\mathrm{N}$ kapsamı yönünden az olduğu belirlenmiştir. Bu durumda mineralizasyon miktarının düşük olduğu söylenebilir. Pırasa ve yer fistığı tarlalarının toprakları alınabilir P içeriği bakımından incelendiğinde sırasıyla \% 11.11'inin yeterli ve \% 88.89'unun 
fazla; \% 83.33'ünün yeterli ve \% 16.67'sinin fazla olduğu saptanmıştır. Pırasa yetiştirilen toprakların ortalama alınabilir K içeriği $207 \mathrm{mg} \mathrm{kg}{ }^{-1}$ iken, yer fistığı yetiştirilen topraklarda bu değer $165.40 \mathrm{mg} \mathrm{kg}^{-1}$ olarak belirlenmiştir. Alınabilir Ca içeriği bakımından pırasa yetiştirilen toprakların \% 51.85' inin yeterli, \% 48.15'inin fazla; yer fıstığı yetiştirilen toprakların ise tamamı fazla sınıfta olduğu saptanmıştır. Pırasa yetiştirilen toprakların alınabilir Mg bakımından \% 44.44' ü yeterli, \% 55.56'sı fazla; yer fistığı toprakları ise \% 66.67'si yeterli, \% 33.33' ü fazla sınıf içerisinde belirlenmiştir.

Çizelge 2. Pırasa ve yer fistığı tarlalarındaki toprakların fizikokimyasal özelliklerinin tanımlayıcı istatistikleri Table 2. Descriptive statistics for physico-chemical characteristics of leek and peanut-grown soils

\begin{tabular}{|c|c|c|c|c|c|c|}
\hline & \multicolumn{3}{|c|}{ Pırasa tarlası $(\mathrm{n}=27)$} & \multicolumn{3}{|c|}{ Yer fistığ } \\
\hline & $\begin{array}{l}\text { Ortalama } \pm \text { standart } \\
\text { sapma }\end{array}$ & En az & En fazla & Ortalama \pm standart sapma & En az & En fazla \\
\hline$\%$ Kil & $24.82 \pm 2.72$ & 20.56 & 29.82 & $17.37 \pm 14.13$ & 9.08 & 47.89 \\
\hline$\%$ Silt & $30.31 \pm 4.19$ & 23.26 & 39.34 & $19.87 \pm 8.66$ & 6.06 & 31.90 \\
\hline \% İnce kum & $32.46 \pm 4.32$ & 24.38 & 40.53 & $62.78 \pm 21.21$ & 11.22 & 60.86 \\
\hline \% Kaba kum & $12.41 \pm 2.84$ & 8.22 & 19.03 & $44.30 \pm 15.58$ & 5.81 & 27.98 \\
\hline $\mathrm{pH}$ & $7.52 \pm 0.30$ & 6.89 & 8.00 & $7.21 \pm 0.52$ & 6.21 & 7.79 \\
\hline $\mathrm{EC}\left(\mathrm{dS} \mathrm{m}^{-1}\right)$ & $1.21 \pm 0.57$ & 0.51 & 2.52 & $0.65 \pm 0.30$ & 0.21 & 1.24 \\
\hline \% Kireç & $5.17 \pm 2.31$ & 1.20 & 13.90 & $1.89 \pm 1.41$ & 0.10 & 5.00 \\
\hline \% Org.madde & $1.54 \pm 0.37$ & 1.00 & 2.39 & $1.15 \pm 0.39$ & 0.70 & 1.90 \\
\hline Toplam N (\%) & $0.08 \pm 0.02$ & 0.05 & 0.12 & $0.07 \pm 0.02$ & 0.04 & 0.10 \\
\hline $\begin{array}{l}\text { Alınabilir P } \\
\left(\mathrm{mg} \mathrm{kg}^{-1}\right)\end{array}$ & $49.38 \pm 16.39$ & 15.01 & 75.97 & $21.72 \pm 5.31$ & 12.75 & 36.32 \\
\hline $\begin{array}{l}\text { Alınabilir K } \\
\left(\mathrm{mg} \mathrm{kg}^{-1}\right)\end{array}$ & $207.00 \pm 83.90$ & 59.76 & 484.60 & $165.40 \pm 143.70$ & 59.72 & 504.48 \\
\hline $\begin{array}{c}\text { Alınabilir Ca } \\
\left(\mathrm{mg} \mathrm{kg}^{-1}\right)\end{array}$ & $3644.70 \pm 713.62$ & 2430.00 & 4563.00 & $4214.88 \pm 289.84$ & 3712.00 & 4581.00 \\
\hline $\begin{array}{c}\text { Alınabilir } \mathrm{Mg} \\
\left(\mathrm{mg} \mathrm{kg}^{-1}\right)\end{array}$ & $507.85 \pm 127.00$ & 269.00 & 894.00 & $413.05 \pm 125.71$ & 190.00 & 586.00 \\
\hline
\end{tabular}

Pırasa tarlasındaki toprakların alınabilir $\mathrm{Fe}, \mathrm{Cu}, \mathrm{Mn}, \mathrm{Zn}, \mathrm{Cr}$, Ni ve $\mathrm{Pb}$ içerikleri sırasıyla $13.71 \mathrm{mg} \mathrm{kg}^{-1}, 2.17 \mathrm{mg}$ $\mathrm{kg}^{-1}, 12.82 \mathrm{mg} \mathrm{kg}^{-1}, 2.67 \mathrm{mg} \mathrm{kg}^{-1}, 0.02 \mathrm{mg} \mathrm{kg}^{-1}, 0.87 \mathrm{mg} \mathrm{kg}^{-1}$ ve $1.35 \mathrm{mg} \mathrm{kg}^{-1}$ olarak saptanmıştır (Çizelge 4). Mordoğan ve ark., (2019) İzmir-Torbalı'daki pırasa yetiştirilen 30 tarladan almış oldukları yüzey topraklarında (0$30 \mathrm{~cm}$ ) alınabilir Fe, $\mathrm{Cu}, \mathrm{Mn}$ ve $\mathrm{Zn}$ içeriklerini sırasıyla $10.21 \mathrm{mg} \mathrm{kg}^{-1}, 2.95 \mathrm{mg} \mathrm{kg}^{-1}, 10.58 \mathrm{mg} \mathrm{kg}^{-1}$ ve $0.91 \mathrm{mg} \mathrm{kg}^{-1}$ olarak rapor etmişlerdir. Torbalı ilçesindeki pırasa tarlasının toprakların toplam $\mathrm{Fe}, \mathrm{Cu}, \mathrm{Mn}, \mathrm{Zn}, \mathrm{Cr}, \mathrm{Ni}$ ve $\mathrm{Pb}$ içerikleri ise sırasıyla $14311.33 \mathrm{mg} \mathrm{kg}-1$, $29.15 \mathrm{mg} \mathrm{kg}^{-1}, 398.58 \mathrm{mg} \mathrm{kg}{ }^{-1}, 61.84 \mathrm{mg} \mathrm{kg}^{-1}, 48 \mathrm{mg} \mathrm{kg}^{-1}, 47.61 \mathrm{mg} \mathrm{kg}^{-1}$ ve $6.96 \mathrm{mg} \mathrm{kg}^{-1}$ olarak saptanmıştır. Yer fistığı tarlasındaki toprakların alınabilir $\mathrm{Fe}, \mathrm{Cu}, \mathrm{Mn}, \mathrm{Zn}, \mathrm{Cr}, \mathrm{Ni}$ ve $\mathrm{Pb}$ içerikleri sırasıyla $11.07 \mathrm{mg} \mathrm{kg}^{-1}, 1.66 \mathrm{mg} \mathrm{kg}^{-1}, 14.83 \mathrm{mg} \mathrm{kg}^{-1}, 0.73 \mathrm{mg} \mathrm{kg}^{-1}, 0.03 \mathrm{mg} \mathrm{kg}^{-1}, 1.24 \mathrm{mg} \mathrm{kg}^{-1} \mathrm{ve} 1.10 \mathrm{mg}$ $\mathrm{kg}^{-1}$ olarak saptanmıştır. Hem pırasa hem de yer fistığı yetiştirilen topraklarda $\mathrm{Zn}$ noksanlığ 1 olan tarlalara Zn katkılı gübreler verilmelidir. Yer fistığı yetiştirilen toprakların toplam $\mathrm{Fe}, \mathrm{Cu}, \mathrm{Mn}, \mathrm{Zn}, \mathrm{Cr}$, $\mathrm{Ni}$ ve $\mathrm{Pb}$ içerikleri ise sırasıyla $12069.33 \mathrm{mg} \mathrm{kg}^{-1}, 31.24 \mathrm{mg} \mathrm{kg}^{-1}, 422.52 \mathrm{mg} \mathrm{kg}^{-1}, 34.74 \mathrm{mg} \mathrm{kg}^{-1}, 66.97 \mathrm{mg} \mathrm{kg}^{-1}$, $50.73 \mathrm{mg} \mathrm{kg}^{-1}$ ve $10.12 \mathrm{mg} \mathrm{kg}^{-1}$ olarak belirlenmiştir. Demir içerikleri yönünden topraklar arasında önemli farklılıklar bulunmaktadır. Topraklarda toplam demir genelde yüksek olmasına karşın bitkiye yarayışı olarak toplam demir miktarının topraklarda $<\% 1$ ile $>\% 20$ arasında değiştiği ve ortalama miktarın ise \% 3.8 olduğu rapor edilmiştir (Kacar, 2019).

Toplam bakır miktarları toprakları oluşturan ana materyale, oluşum koşullarına ve işlemlere göre değişmektedir. Toplam bakır topraklarda genellikle 2 ile $200 \mathrm{mg} \mathrm{Cu} \mathrm{kg}^{-1}$ arasında değişmektedir (Kacar, 2019). Topraklarda 
mangan miktarının 20 ile $3000 \mathrm{mg} \mathrm{Mn} \mathrm{kg}{ }^{-1}$ arasında değiştiği ortalama miktarının $600 \mathrm{mg} \mathrm{Mn} \mathrm{kg}{ }^{-1}$ olduğu rapor edilmiştir (Kacar, 2019). Toprakların çinko içerikleri genelde: (a) Toprak tipine, (b) Uygulanan tarım tekniğine, (c) Çevrenin iklimine, (d) Bitki çeşidine ve (e) Topraktan kaldırılan ürün miktarına bağlı olarak değişmektedir. Kirlenmemiş tarım topraklarında çinko miktarının 17 ile $160 \mathrm{mg} \mathrm{Zn} \mathrm{kg}^{-1}$ arasında değiştiği rapor edilmiştir. Tipik tarım topraklarında çinko miktarı, 10 ile $300 \mathrm{mg} \mathrm{Zn} \mathrm{kg}^{-1}$ arasında değişmekte olup ortalama miktar $50 \mathrm{mg} \mathrm{Zn} \mathrm{kg}$ ${ }^{1}$ 'dır (Kacar, 2019).

Çizelge 3. Pırasa $(n=27)$ ve yer fistığı yetiştirilen toprakların $(n=18)$ kimyasal özellikleri ile bazı bitki besin elementi içeriklerinin dağılımı ve sınıflandırılması

Table 3. Distribution and classification of chemical characteristics and nutrient contents of leek $(n=27)$ and peanut $(n=18)$ grown soils

\begin{tabular}{|c|c|c|c|c|}
\hline Özellik & $\begin{array}{c}\text { Sinır } \\
\text { Değerleri }\end{array}$ & Tanımlama & $\begin{array}{c}\text { Pirasa toprakları } \\
(\%)\end{array}$ & $\begin{array}{c}\text { Yer fistığı toprakları } \\
(\%)\end{array}$ \\
\hline \multirow{6}{*}{$\begin{array}{l}\text { Toprak reaksiyonu } \\
\text { (Anonim, 1988) }\end{array}$} & $<4.5$ & Kuvvetli asit & - & - \\
\hline & $4.5-5.5$ & Orta asit & - & - \\
\hline & $5.5-6.5$ & Hafif asit & - & 16.67 \\
\hline & $6.5-7.5$ & Nötr & 44.44 & 38.89 \\
\hline & $7.5-8.5$ & Hafif alkali & 55.56 & 44.44 \\
\hline & $>8.5$ & Kuvvetli alkali & - & - \\
\hline \multirow{4}{*}{$\begin{array}{l}\text { Elektriksel iletkenlik (EC, } \\
\text { dS m }{ }^{-1} \text { ) } \\
\text { (Richards, 1954) }\end{array}$} & $<2$ & Tuzsuz & 100.00 & 100.00 \\
\hline & $2-4$ & Hafif tuzlu & - & - \\
\hline & $4-8$ & Orta tuzlu & - & - \\
\hline & $8-15$ & Çok tuzlu & - & - \\
\hline \multirow{5}{*}{$\begin{array}{l}\mathrm{CaCO}_{3}\left(\mathrm{~g} \mathrm{~kg}^{-1}\right) \\
\text { (Anonim, 1988) }\end{array}$} & $<10$ & Az kireçli & - & 33.33 \\
\hline & $10-50$ & Kireçli & 66.67 & 66.67 \\
\hline & $50-150$ & Orta & 33.33 & - \\
\hline & $150-250$ & Fazla & - & - \\
\hline & $>250$ & Çok fazla & - & - \\
\hline \multirow{5}{*}{$\begin{array}{l}\text { Organik madde }\left(\mathrm{g} \mathrm{kg}^{-1} \text { ) }\right. \\
\text { (Anonim, 1988) }\end{array}$} & $<10$ & Çok az & - & 55.56 \\
\hline & $10-20$ & $\mathrm{Az}$ & 92.59 & 44.44 \\
\hline & $20-30$ & Orta & 7.41 & - \\
\hline & $30-40$ & İyi & - & - \\
\hline & $>40$ & Yüksek & - & - \\
\hline \multirow{5}{*}{$\begin{array}{l}\text { Toplam N }\left(\mathrm{g} \mathrm{kg}^{-1}\right) \\
(\mathrm{FAO}, 1990)\end{array}$} & $<0.45$ & Çok az & - & - \\
\hline & $0.45-0.90$ & $\mathrm{Az}$ & 100.00 & 100.00 \\
\hline & $0.90-1.70$ & Yeterli & - & - \\
\hline & $1.70-3.20$ & Fazla & - & - \\
\hline & $>3.20$ & Çok fazla & - & - \\
\hline \multirow{4}{*}{$\begin{array}{l}\text { Alınabilir P }\left(\mathrm{mg} \mathrm{kg}^{-1}\right) \\
(\text { FAO, 1990) }\end{array}$} & $<2.5$ & Çok az & - & - \\
\hline & $2.5-8.0$ & $\mathrm{Az}$ & - & - \\
\hline & $8-25$ & Yeterli & 11.11 & 83.33 \\
\hline & $25-80$ & Fazla & 88.89 & 16.67 \\
\hline
\end{tabular}




\begin{tabular}{|c|c|c|c|c|}
\hline \multirow{5}{*}{$\begin{array}{l}\text { Alınabilir K }\left(\mathrm{mg} \mathrm{kg}^{-1}\right) \\
\text { (FAO, 1990) }\end{array}$} & $<50$ & Çok az & - & - \\
\hline & $50-110$ & $\mathrm{Az}$ & - & 50.00 \\
\hline & $110-290$ & Yeterli & 11.11 & - \\
\hline & $290-1000$ & Fazla & 85.19 & 33.33 \\
\hline & $>1000$ & Çok fazla & 3.70 & 16.67 \\
\hline \multirow{5}{*}{$\begin{array}{l}\text { Alınabilir Ca (mg kg-1) } \\
(\mathrm{FAO}, 2008)\end{array}$} & $<238$ & Çok az & - & - \\
\hline & $238-1150$ & $\mathrm{Az}$ & - & - \\
\hline & $1150-3500$ & Yeterli & 51.85 & - \\
\hline & $3500-10000$ & Fazla & 48.15 & 100.00 \\
\hline & $>10000$ & Çok fazla & - & - \\
\hline Alınabilir Mg (mg kg-1) & $<50$ & Çok az & - & - \\
\hline \multirow[t]{4}{*}{$(\mathrm{FAO}, 2008)$} & $50-160$ & $\mathrm{Az}$ & - & - \\
\hline & $160-480$ & Yeterli & 44.44 & 66.67 \\
\hline & $480-1500$ & Fazla & 55.56 & 33.33 \\
\hline & $>1000$ & Çok fazla & - & - \\
\hline Alınabilir Fe (mg kg-1) & $<2$ & Çok az & - & - \\
\hline \multirow[t]{4}{*}{ (FAO, 2008) } & $2-4$ & $\mathrm{Az}$ & - & - \\
\hline & $4-6$ & Yeterli & 3.70 & - \\
\hline & $6-10$ & Fazla & 33.33 & 72.22 \\
\hline & $>10$ & Çok fazla & 62.97 & 27.78 \\
\hline Alınabilir $\mathrm{Cu}\left(\mathrm{mg} \mathrm{kg}^{-1}\right)$ & $<0.1$ & Çok az & - & - \\
\hline \multirow[t]{4}{*}{ (FAO, 2008) } & $0.1-0.3$ & $\mathrm{Az}$ & - & - \\
\hline & $0.3-0.8$ & Yeterli & - & - \\
\hline & $0.8-3.0$ & Fazla & 88.89 & 94.44 \\
\hline & $>3.0$ & Çok fazla & 11.11 & 5.56 \\
\hline Alınabilir Mn (mg kg $\left.{ }^{-1}\right)$ & $<0.5$ & Çok az & - & - \\
\hline \multirow[t]{4}{*}{ (FAO, 2008) } & $0.5-1.2$ & $\mathrm{Az}$ & - & - \\
\hline & $1.2-3.5$ & Yeterli & - & - \\
\hline & $3.5-6.0$ & Fazla & - & - \\
\hline & $>6.0$ & Çok fazla & 100.00 & 100.00 \\
\hline Alınabilir Zn (mg kg-1) & $<0.5$ & Çok az & - & 22.22 \\
\hline \multirow[t]{4}{*}{$(\mathrm{FAO}, 2008)$} & $0.5-1.0$ & $\mathrm{Az}$ & 7.41 & 61.11 \\
\hline & $1.0-3.0$ & Yeterli & 55.56 & 16.67 \\
\hline & $3.0-5.0$ & Fazla & 37.03 & - \\
\hline & $>5.0$ & Çok fazla & - & - \\
\hline
\end{tabular}

Dünyadaki yüzey topraklarında ortalama krom içeriği $54 \mathrm{mg} \mathrm{kg}^{-1}$ 'dır. Topraktaki krom ana materyalden kaynaklanabileceği gibi çeşitli endüstriyel atıklardan (elektro kaplama çamurlama, krom pigment ve tabakhane atıkları, deri imalat atıkları) ile atık çamurdan da kaynaklanmaktadır (Kabata-Pendias ve Pendias, 2011). 
Topraklarda nikel, ana materyalin kapsamına bağlı olarak değişmektedir. Yüzey topraklarında nikel konsantrasyonu, toprak oluşum süreci ve kirlenme durumunu göstermektedir. Dünyadaki topraklarda nikel içeriği 0.2 ile $450 \mathrm{mg} \mathrm{kg}^{-1}$ arasında değişmektedir (Kabata-Pendias ve Pendias, 2011).Toprakların kurşun içeriği ana materyalden kaynaklanmaktadır. Topraklar 10 ile $67 \mathrm{mg} \mathrm{kg}^{-1}$ ortalama olarak $32 \mathrm{mg} \mathrm{kg}^{-1}$ kurşun içermektedirler. Kurşun aynı zamanda antropojenik etkilerden de (motorlu araçlarda kullanılan benzin, katı ve sıvı yakıtların yakılması, pirinç imalathaneleri, kurşun elde etme firınları) kaynaklanmaktadır (Kabata-Pendias ve Pendias, 2011).

Pırasa tarımı yapılan topraklarda $\mathrm{Cu}, \mathrm{Zn}$ ve Ni'in zenginleşme faktörü 2'den büyük; $\mathrm{Mn}, \mathrm{Cr}$ ve $\mathrm{Pb}$ 'nin zenginleşme faktörü 2 'den küçük bulunmuştur.

Çizelge 4. Pırasa ve yer fistı̆̆ tarlalarındaki toprakların alınabilir ve toplam ağır metal içerikleri $\left(\mathrm{mg} \mathrm{kg}^{-1}\right)$

Table 4. Available and total heavy metal content of soils $\left(\mathrm{mg} \mathrm{kg}^{-1}\right)$ in leek and peanut fields

\begin{tabular}{lcccccc}
\hline & \multicolumn{3}{c}{ Pırasa tarlası $(\mathrm{n}=27)$} & \multicolumn{3}{c}{ Yer fistı̆̆ tarlası $(\mathrm{n}=18)$} \\
\cline { 2 - 7 } & Ortalama \pm standart sapma & En az & En fazla & Ortalama \pm standart sapma & En az & En fazla \\
\hline Alınabilir Fe & $13.71 \pm 7.52$ & 5.92 & 36.38 & $11.07 \pm 4.94$ & 7.66 & 22.44 \\
Alınabilir $\mathrm{Cu}$ & $2.17 \pm 0.59$ & 1.41 & 3.75 & $1.66 \pm 0.55$ & 0.99 & 3.04 \\
Alınabilir Mn & $12.82 \pm 4.52$ & 9.68 & 29.82 & $14.83 \pm 6.96$ & 6.80 & 30.72 \\
Alınabilir $\mathrm{Zn}$ & $2.67 \pm 0.92$ & 0.71 & 4.61 & $0.73 \pm 0.31$ & 0.38 & 1.56 \\
Alınabilir Cr & $0.02 \pm 0.01$ & 0.01 & 0.03 & $0.03 \pm 0.005$ & 0.02 & 0.03 \\
Alınabilir Ni & $0.87 \pm 0.33$ & 0.43 & 1.68 & $1.24 \pm 0.92$ & 0.35 & 2.94 \\
Alınabilir Pb & $1.35 \pm 0.68$ & 0.50 & 2.62 & $1.10 \pm 0.43$ & 0.48 & 1.83 \\
Toplam Fe & $14311.33 \pm 1756.88$ & 9151.00 & 17350.00 & $12069.33 \pm 4875.15$ & 3776.50 & 17950.00 \\
Toplam Cu & $29.15 \pm 4.66$ & 16.36 & 37.07 & $31.24 \pm 10.98$ & 12.62 & 45.14 \\
Toplam Mn & $398.58 \pm 59.97$ & 290.10 & 620.75 & $422.52 \pm 158.96$ & 104.31 & 614.75 \\
Toplam Zn & $61.84 \pm 17.32$ & 22.83 & 108.10 & $34.74 \pm 19.37$ & 2.44 & 59.06 \\
Toplam Cr & $48.00 \pm 17.18$ & 26.56 & 112.98 & $66.97 \pm 59.85$ & 7.78 & 228.67 \\
Toplam Ni & $47.61 \pm 11.91$ & 23.28 & 74.04 & $50.73 \pm 45.66$ & 3.49 & 171.42 \\
Toplam Pb & $6.96 \pm 4.34$ & 1.76 & 18.12 & $10.12 \pm 7.82$ & 0.77 & 21.26 \\
\hline
\end{tabular}

Yer fistığ ( $\mathrm{Mn}, \mathrm{Zn}, \mathrm{Cr}$ ve $\mathrm{Pb}$ ) zenginleşme faktörü 2'den küçük saptanmıştır (Çizelge 5). Bakırın zenginleşme faktörünün orta zenginlikte olmasının nedeni toprağa bakterisit, algisit, fungisit ve gübrelerin tarımsal aktiviteler nedeniyle fazla miktarda ilave edilmesidir (Parlak ve ark., 2019; Shabbir ve ark., 2020). Yapılan başka bir araştırmada kereviz yetiştirilen tarlalardaki topraklarda $\mathrm{Cu}$ ' nun zenginleşme faktörü 2.06 olarak bulunmuştur (Parlak ve ark., 2020).

Cu' nun kirlilik faktörü pırasa ve yer fistığı yetiştirilen topraklarda 1'den büyük diğer ağır metallerinki (Mn, Zn, $\mathrm{Cr}, \mathrm{Ni}$ ve $\mathrm{Pb}$ ) ise 1'den küçük bulunmuştur (Çizelge 5).

Torbalı ve Bayramiç İlçelerindeki toprakların Fe içerikleri Sinop İli, Argolida Havzası, Zhejiang İli ve Dünya topraklarından düşük saptanmışken, Cu kapsamları Bafra Ovası, Zhejiang İli ve Dünya topraklarından yüksek; Geyve İlçesi, Sinop İli, Anonim (2005) ve Argolida Havzası topraklarından düşük olarak belirlenmiştir (Çizelge 6). Her iki ilçedeki toprakların Mn içerikleri Geyve İlçesi, Argolida Havzası, Zhejiang İli ve Dünya topraklarından düşük olarak belirlenmiştir. Torbalı İlçesindeki toprakların Zn kapsamı Geyve İlçesi, Sinop İli, Argolida Havzası, Anonim (2005), Zhejiang İli ve Dünya topraklarından düşük, Bafra Ovası topraklarından yüksek olduğu saptanmıştır. Bayramiç ilçesi'ndeki toprakların Zn içeriği diğer alanlardaki tarım topraklarından (Geyve İlçesi, Sinop ili, Bafra Ovası, Anonim(2005), Argolida Havzası, Zhejiang İli ve Dünya toprakları) düşük bulunmuştur. Torbalı İlçesi'ndeki toprakların Zn kapsamı Geyve ilçesi, Sinop ili, Anonim (2005), Zhejiang İli ve Dünya topraklarında düşük; Bafra Ovası topraklarında ise yüksek saptanmıştır. Bayramiç İlçesi'ndeki toprakların Zn içeriği diğer alanlardaki tarım topraklarından (Geyve İlçesi, Sinop ili, Bafra Ovası, Anonim (2005), Argolida Havzası, Zhejiang İli ve Dünya toprakları) düşük saptanmıştır. Torbalı İlçesi’ndeki toprakların Cr içeriği Geyve İlçesi, Sinop ili, Anonim (2005), Argolida Havzası ve dünya topraklarınkinden düşük iken Bayramiç İlçesi'ndeki toprakların $\mathrm{Cr}$ 
içeriği Geyve İlçesi, Zhejiang İli ve Dünya topraklarınkinden yüksek; Sinop ili, Anonim (2005) ve Argolida Havzası topraklarından düşük bulunmuştur. Torbalı ve Bayramiç İlçesi’ndeki tarım topraklarının Ni içerikleri Geyve İlçesi, Sinop İli, Bafra Ovası, Anonim (2005) ve Argolida Havzası topraklarından düşük; Zhejiang İli ve Dünya topraklarınkinden yüksek belirlenmiştir. Her iki çalışma alanındaki toprakların $\mathrm{Pb}$ içerikleri diğerlerinden (Geyve İlçesi, Sinop ili, Bafra Ovası, Anonim (2005), Argolida Havzası, Zhejiang İli ve Dünya toprakları) düşük olarak belirlenmiştir.

Çizelge 5. Pırasa ve yer fistığı tarlalarındaki topraklarda ağır metallerin zenginleşme ve kirlilik faktörleri Table 5. Heavy metal enrichment and pollution factors of soils in leek and peanut fields

\begin{tabular}{lcccccc}
\hline & \multicolumn{3}{c}{ Pirasa toprakları } & \multicolumn{4}{c}{ Yer fistığ toprakları } \\
\hline & Ortalama \pm standart sapma & En az & En fazla & Ortalama \pm standart sapma & En az & En fazla \\
\hline $\mathrm{EF}_{\mathrm{Cu}}$ & $3.05 \pm 0.53$ & 1.70 & 4.34 & $3.35 \pm 1.24$ & 1.25 & 5.47 \\
$\mathrm{EF}_{\mathrm{Mn}}$ & $1.46 \pm 0.26$ & 1.05 & 2.40 & $1.59 \pm 0.61$ & 0.36 & 2.35 \\
$\mathrm{EF}_{\mathrm{Zn}}$ & $2.49 \pm 0.69$ & 0.91 & 4.07 & $1.44 \pm 0.81$ & 0.10 & 2.56 \\
$\mathrm{EF}_{\mathrm{Cr}}$ & $1.00 \pm 0.41$ & 0.55 & 2.66 & $1.45 \pm 1.05$ & 0.15 & 6.17 \\
$\mathrm{EF}_{\mathrm{Ni}}$ & $2.23 \pm 0.62$ & 1.08 & 3.92 & $2.49 \pm 1.47$ & 0.15 & 10.41 \\
$\mathrm{EF}_{\mathrm{Pb}}$ & $1.22 \pm 0.74$ & 0.31 & 2.99 & $1.83 \pm 1.43$ & 0.14 & 3.97 \\
$\mathrm{CF}_{\mathrm{Cu}}$ & $1.16 \pm 0.19$ & 0.65 & 1.48 & $1.24 \pm 0.44$ & 0.50 & 1.81 \\
$\mathrm{CF}_{\mathrm{Mn}}$ & $0.55 \pm 0.08$ & 0.40 & 0.87 & $0.59 \pm 0.22$ & 0.15 & 0.86 \\
$\mathrm{CF}_{\mathrm{Zn}}$ & $0.95 \pm 0.27$ & 0.35 & 1.66 & $0.54 \pm 0.29$ & 0.04 & 0.91 \\
$\mathrm{CF}_{\mathrm{Cr}}$ & $0.38 \pm 0.14$ & 0.21 & 0.90 & $0.53 \pm 0.47$ & 0.06 & 1.81 \\
$\mathrm{CF}_{\mathrm{Ni}}$ & $0.85 \pm 0.21$ & 0.42 & 1.32 & $0.91 \pm 0.81$ & 0.06 & 3.06 \\
$\mathrm{CF}_{\mathrm{Pb}}$ & $0.47 \pm 0.29$ & 0.12 & 1.22 & $0.68 \pm 0.53$ & 0.05 & 1.44 \\
\hline
\end{tabular}

Çizelge 6. Dünyada farklı alanlardaki tarım topraklarının ortalama ağır metal konsantrasyonları( $\left.\mathrm{mg} \mathrm{kg}^{-1}\right)$ Table 6. Average heavy metal concentrations $\left(\mathrm{mg} \mathrm{kg}^{-1}\right)$ of agricultural soils in different areas of the world

\begin{tabular}{|c|c|c|c|c|c|c|c|c|c|}
\hline & & $\mathrm{Fe}$ & $\mathrm{Cu}$ & Mn & $\mathrm{Zn}$ & $\mathrm{Cr}$ & $\mathrm{Ni}$ & $\mathrm{Pb}$ & Kaynak \\
\hline \multirow{3}{*}{$\begin{array}{l}\text { Torbal1 } \\
\text { (İzmir) }\end{array}$} & Ortalama & 14311.33 & 29.15 & 398.58 & 61.84 & 48 & 47.61 & 6.96 & $\mathrm{Bu}$ araştırma \\
\hline & En az & 9151 & 16.36 & 290.10 & 22.83 & 26.56 & 23.28 & 1.76 & \\
\hline & En fazla & 17350 & 37.07 & 620.75 & 108.10 & 112.98 & 74.04 & 18,12 & \\
\hline \multirow{3}{*}{$\begin{array}{c}\text { Bayramiç } \\
\text { (Çanakkale) }\end{array}$} & Ortalama & 12069.33 & 31.24 & 422.52 & 34.74 & 66.97 & 50.73 & 10.12 & $\mathrm{Bu}$ araştırma \\
\hline & En az & 3776.50 & 12.62 & 104.31 & 2.44 & 7.78 & 3.49 & 0.77 & \\
\hline & En fazla & 17950 & 45.14 & 614.75 & 59.06 & 228.67 & 171.42 & 21.26 & \\
\hline $\begin{array}{c}\text { Geyve } \\
\text { (Sakarya) }\end{array}$ & & - & 54.95 & 610.27 & 71.05 & 56.48 & 56.25 & 15.69 & $\begin{array}{l}\text { Parlak ve ark., } \\
2020\end{array}$ \\
\hline Sinop İli & & 39848.57 & 43.19 & - & 65.10 & 194.73 & 85.02 & 17.01 & $\begin{array}{l}\text { Baltaş ve ark., } \\
2020\end{array}$ \\
\hline $\begin{array}{l}\text { Bafra Ovas1 } \\
\text { (Samsun) }\end{array}$ & & - & 28.77 & - & 56.17 & - & 81.94 & 21.99 & $\begin{array}{c}\text { Kizılkaya ve ark., } \\
2011\end{array}$ \\
\hline
\end{tabular}




\begin{tabular}{|c|c|c|c|c|c|c|c|c|}
\hline Anonim, 2005 & - & 140 & - & 300 & 100 & 75 & 300 & Anonim, 2005 \\
\hline $\begin{array}{c}\text { Argolida } \\
\text { (Yunanistan) }\end{array}$ & 26500 & 74.68 & 1020.50 & 74.88 & 83.12 & 146.80 & 19.74 & Kelepertzis, 2014 \\
\hline $\begin{array}{l}\text { Zhejiang } \\
\text { (Çin) }\end{array}$ & 29900 & 23.21 & 709.23 & 83.75 & 61.86 & 22.81 & 33.03 & $\begin{array}{l}\text { Jiang ve ark., } \\
2015\end{array}$ \\
\hline $\begin{array}{c}\text { Dünya } \\
\text { Toprakları }\end{array}$ & 40000 & 19.80 & 437 & 64 & 54 & 22 & 28.60 & $\begin{array}{c}\text { Kabata-Pendias } \\
\text { ve Pendias, } 2011\end{array}$ \\
\hline
\end{tabular}

\section{Sonuç}

Bu çalışmada İzmir-Torbalı ve Çanakkale-Bayramiç ilçelerinde pırasa ve yer fistığı tarımı yapılan toprakların verimlilik durumları ile ağır metal içerikleri araştırılmıştır. Pırasa ve yer fıstı̆̆̆ yetiştirilen alanlardaki toprakların çoğunda organik madde, tamamında toplam $\mathrm{N}$ bakımından sorunlar saptanmıştır. Hem pırasa hem de yer fistığ tarımı yapılan toprakların tamamı alınabilir $\mathrm{Fe}, \mathrm{Cu}, \mathrm{Mn}$ konsantrasyonları noksanlık göstermezken alınabilir $\mathrm{Zn}$ bakımından pırasa yetiştirilen toprakların \% 7.41'i az, yer fistığ yetiştirilen toprakların \% 22.22'si çok az, \% 61.11' $\mathrm{i}$ ise az sınıfında belirlenmiştir. Her iki alandaki topraklara düzenli olarak yeşil gübreleme, yanmış ahır gübresi, kompost vb. uygulamalar ile organik madde miktarını artıracak uygulamalar yapılmalıdır. Araştırılan alanlardaki kirlenmenin yoğunluğu zenginleşme faktörü ve kirlenme faktörü kullanılarak belirlenmiştir. Pırasa yetiştirilen alanda $\mathrm{Cu}, \mathrm{Zn}$ ve Ni'in zenginleşme faktörü orta zenginlikte; yer fistığı yetiştirilen alanda ise Cu ve Ni'in zenginleşme faktörü orta zenginlikte saptanmıştır. Her iki alanda araştırılan ağır metaller içerisinde en yüksek kirlilik faktörü $\mathrm{Cu}$ için saptanmıştır.

\section{Teşekkür}

$\mathrm{Bu}$ çalışma Çanakkale Onsekiz Mart Üniversitesi Bilimsel Araştırma Projeleri Koordinasyon Birimince Desteklenmiştir. Proje Numarası: FHD-2019-3068.

\section{Kaynaklar}

Aka Sağlıker, H., Elmasoğlu, C., 2020. Osmaniye yer fistığı ve topraklarının bazı ekolojik özelliklerinin ilçeler arasında karşılaştırmalı olarak incelenmesi. Anadolu Çevre ve Hayvancıllk Bilimleri Dergisi 5(4):460-465.

Anonim, 1988. Türkiye Gübre ve Gübreleme Rehberi (3. baskı). T.C. Tarim Orman Köyişleri Bakanliği, Köy Hizmetleri Genel Müdürlüğü, Toprak Ve Gübre Araştirma Enstitüsü Müdürlüğü Yayınlari, Genel Yayın No: 151, Teknik Yayinlar No: t-59, Ankara, 182 sy.

Anonim, 2005. Toprak kirliliğinin kontrolü yönetmeliği. 31 Mayıs 2005 Tarih ve 25831 Sayılı Resmi Gazete, Ankara.

Anonim, 2019a. FAOSTAT. Food and Agriculture Data. http:www.fao.org/faostat/en (Alınma Tarihi: 30.03.2019).

Anonim, 2019b. Tarım verileri. http://www.tuik.gov.tr/ (Alınma Tarihi:30.03. 2019).

Anonim, 2020a. http://www.torbali.gov.tr/ (Alınma Tarihi:12.09.2020).

Anonim, 2020b. http://www.bayramic.bel.tr/ (Alınma Tarihi:12.09. 2020).

Anonim, 2020c. http://www.bayramic.gov.tr/ (Alınma Tarihi:12.09.2020).

Baltas, H., Sirin, M., Gökbayrak, E., Ozcelik, A. E., 2020. A case study on pollution and a human health risk assessment of heavy metals in agricultural soils around Sinop province, Turkey. Chemosphere 241: doi: 10.1016/j.chemosphere.2019.125015.

Bremner, J. M., 1996. Nitrogen - total. In: Sparks, D.L. (Ed.), Methods of Soil Analysis. Part 3. Chemical Methods. 1085-1122. American Society of Agronomy, Madison, Wisconsin, USA

DOĞAKA, 2015. TR 63 Bölgesi Yer fistı̆̆ı Sektör Raporu. T.C. Doğu Akdeniz Kalkınma Ajansı. Hatay. 25 sy.

FAO, 1990. Micronutrients Assessment at the Country Level. An international study (Ed. M. Sillanpaa) FAO Soil Bulletin 63. Published by FAO. Roma, Italy. 128 pp.

FAO, 2008. Guide to Laboratory Establishment for Plant Nutrient Analysis. FAO Fertilizer and Plant Nnutrition Bulletin 19 (Eds. M.R. Motsara, R.N. Roy), Rome. ISBN 978-92-5-10598.

Geçit, H. H., Çiftçi, C.Y., Emeklier, C.Y., İkincikarakaya, S., Adak, M.S., Kolsarıcı, Ö., Ekiz, H., Altınok, S., Sancak, C., Sevimay, C.S., Kendir, H., 2011. Tarla Bitkileri. Ankara Üniversitesi Ziraat Fakültesi Yayınları Yayın no: 1588, Ders Kitabı: 540. Ankara.

Gee, G.W., Or, D., 2002. Particle-size analysis. pages 255-293. in J.H. Dane, G.C. Topp, eds. Methods of Soil Analysis. Part 4, Physical Methods. SSSA Book Series 5. Madison, Wisconsin.

Hakanson, L., 1980. An ecological risk index for aquatic pollution control, a sedimentological approach. Water Research 14: 975-1001. 
Helmke, P.A., Sparks, D.L., 1996. Lithium, sodium, potassium, rubidium, and calcium. Pages 551-574. in D.L. Sparks, ed. Methods of Soil Analysis. Part 3. Chemical Methods. American Society of Agronomy, Madison, Wisconsin, USA.

Jiang, C., Jun, Z., Gao, L., 2015. Sources and ecological risk assessment of heavy metal(loid)s in agricultural soils of Huzhou, China. Soil and Sediment Contamination: An international journal 24: 437-453.

Kabata Pendias, A., Pendias, H., 2011. Trace Elements in Soils and Plants. Third edition. Boca Raton, FL: CRC Press.

Kacar, B., 2019. Sürdürülebilir Tarımda Mikro Besin Maddeleri. Nobel Akademik Yayıncılık, Ankara. 736 sy.

Keesstra, S.D., Bouma, J., Wallinga, J., Tittonell, P., Smith, P., Cerda, A., Montanarella, L., Quinton, J.N., Pachepsky, Y., van der Puten, W.H., Bardgett, R.D, Moolenaar, S., Mol, G., Jansen, B., Fresco, L.O., 2016. The significance of soils and soil science towards the realization of the United Nations sustainable development goals. Soil 2: 111-128.

Kelepertzis, E., 2014. Accumulation of heavy metals in agricultural soils of Mediterranean: Insights from Argolida Basin, Peloponnese, Greece. Geoderma 221-222: 82-90.

Kızılkaya, R., Dengiz, O., Özyazıcı, M.A., Aşkın, T., Mikayilov, F., Shein, E., 2011. Spatial distribution of heavy metals status in Bafra Plain soils. Eurasian Soil Science 44(12): 1343-1351.

Kuo, S., 1996. Phosphorus. pages 869-920. in D.L. Sparks, ed. Methods of Soil Analysis. Part 3. Chemical Methods. American Society of Agronomy, Madison, Wisconsin, USA.

Kurucu, Y., Küçükyılmaz Christine, N., 2008. Monitoring the impacts of urbanization and industrialization on the agricultural land and environment of the Torbal1, Izmir region, Turkey. Environmental Monitoring and Assessment 36: 289-297. doi 10.1007/s10661-007-9684-4.

Lindsay, W.L., Norvell, W.A., 1978. Development of a DTPA soil test for Zn, Fe, Mn and Cu. Soil Science of America journal 42 (3): 421-428.

Loeppert, R.H., Suarez, D.L., 1996. Carbonate and gypsum. Pages 437-474.. in D.L. Sparks, ed. Methods of Soil Analysis. Part 3. Chemical Methods. American Society of Agronomy, Madison, Wisconsin, USA.

Mordoğan, N., Erdoğan Bayram, S., Çakıcı, H., Duman, İ., 2019. Brokoli ve pırasada kükürt içeriği ve kükürtlü aminoasit miktarları arasındaki ilişkiler. Harran Tarım Gıda Bil. Derg. 23(3): 263-276.

Nelson, R.E., Sommers, L.E., 1996. Total carbon, organic carbon and organic matter. Pages 961-1010. in D.L. Sparks, ed. Methods of Soil Analysis. Part 3. Chemical Methods. American Society of Agronomy, Madison, Wisconsin, USA.

Parlak, M., Everest, T., Tunçay, T., 2019. Rulo çim alanlarındaki toprakların ve çim bitkisinin bazı ağır metal (Cu, Zn, Cr, Ni, $\mathrm{Pb}$ ) içerikleri: Pilot çalışmalar: Edirne, Balıkesir ve Çanakkale. ÇOMÜ Ziraat Fak. Derg. 7(2): 323-334.

Parlak, M., Çıkılı, Y., Çiçek, G., 2020. Kereviz tarlalarının verimlilik durumları ile ağır metal kapsamlarının toprak ve yaprak analizleriyle belirlenmesi: Sakarya-Geyve Örneği. ÇOMÜ Ziraat Fakültesi Dergisi 8 (1): 173-185.

Petersen, R.G., Calvin, L.D., 1996. Sampling. Pages 1-17. in D.L. Sparks, ed. Methods of Soil Analysis. Part 3. Chemical Methods. American Society of Agronomy, Madison, Wisconsin, USA.

Rhoades, J.D., 1996. Salinity: Electrical conductivity and total dissolved solids. Pages 417-436. in D.L. Sparks, ed. Methods of Soil Analysis. Part 3. Chemical Methods. American Society of Agronomy, Madison, Wisconsin, USA.

Richards, L.A., 1954. Diagnosis and Improvement Saline and Alkaline Soils. U.S. Dep. Agr. Handbook No: 60.160 pp.

SAS Institute Inc, 2018. SAS/entreprise guide version 9.4.

Shabbir, Z., Sardar, A., Shabbir, A., Abbas, G., Shamshad, S., Sana Khalid, N., Murtaza, G., Dumat, C., Shahid, M., 2020. Copper uptake, essentially, toxicity, detoxification and risk assessment in soil-plant environment. Chemosphere 259, doi.org/10.1016/j.chemosphere.2020.127436.

Soil Survey Staff, 2014. Keys to 12th Ed. USDA-Natural Resources Conservation Service. Washington DC. 372 pp.

Thomas, G.W., 1996. Soil pH and soil acidity. Pages 475-490. in D.L. Sparks, ed. Methods of Soil Analysis. Part 3. Chemical Methods. American Society of Agronomy, Madison, Wisconsin, USA.

USEPA (United States Environmental Protection Agency), 1996. Method 3050B: Acid Digestion of Sediments, Sludges, and Soils. (revision 2).

Vural, H., Eşiyok, D., Duman, İ., 2000. Kültür Sebzeleri (Sebze Yetiştirme). Ege Üniversitesi Basımevi, İzmir. 440 sy.

Wedepohl, K.H., 1995. The composition of the continental crust. Geochimica et cosmochimica Acta 59(7): 1217-1232.

Wu J, Lu J, Li L, Min X, Luo, Y., 2018. Pollution, ecological-health risks, and sources of heavy metals in soil of the Northeastern Qinghai-Tibet Plateau. Chemosphere 201: 234-242.

Zengin, M., Özbahçe, A., 2011. Bitkilerin İklim ve Toprak İstekleri. Atlas Akademi Yayın No: 4, Konya, 167 sy. 